\title{
Trading Volume and Fama-French Three Factor Model on Excess Return. Empirical Evidence from Nairobi Security Exchange
}

\author{
Opuodho Gordon Ochere (MBA) \\ Nasieku M. Tabitha (PhD) \\ Olweny Tobias $\mathrm{O}$ (PhD)
}

Department of Economics, Accounts and Finance,

Jomo Kenyatta University of Agriculture and Technology, Kenya

Doi:10.19044/esj.2018.v14n22p276 URL:http://dx.doi.org/10.19044/esj.2018.v14n22p276

\begin{abstract}
The main objective of this paper is to examine the effect of Trading Volume on excess return using the Fama-French three factor model of listed companies in Kenya. The research study employed a Quantitative research design to analyses the effect of Trading Volume on excess returns in Nairobi Security Exchange (NSE) during the period 2006 to 2015. Secondary data was used for this study. The study utilized descriptive statistics, correlation, unit root test, Heteroscedasticity, and Autocorrelation test as diagnostic tests. The regression results revealed that Market premium and Value premium (HML) and Trading Volume have a high explanatory power while the size premium (SMB) has a low explanatory power.
\end{abstract}

Keywords: Trading Volume, SMB, HML, Market Premium and Excess Returns

\section{Introduction:}

Traditional Asset Pricing theory assumes markets are efficient meaning that there are no friction such as taxes and transaction cost. This can be achieved by markets that are liquid and therefore a transaction can be executed as soon as possible. To measure the excess return in the market several Asset pricing models have been developed such as Sharpes CAPM (1954) and Fama French three factor model but so far it is not conclusive how excess return are priced, Riro and Wambugu (2015). Muriu and Achola (2015) also argued that it is probable that these models were mainly developed using data from highly efficient stock market like NYSE, AMEX, and NASDAQ and they may not hold in market classified as emerging such as Kenya. An emerging market has unique characteristics like lower market liquidity, 
inexperienced market participants, shorter history, and domination by institutional investor's especially commercial banks and concentration of trade in a few stocks. It's therefore important for market liquidity to be included in the asset pricing model used to price excess return.

Market liquidity is therefore an important aspect of efficient market and one of the key measures is the trading volume. Trade volume is a manifestation of the ability of the exchange mechanism to reallocate assets across investors. Trading volume is defined as the number of shares traded each day and is an important indicator in technical analysis as it is used to measure the worth of stock price movement either up or down (Abbondante, 2010).

Investors' motive to trade is solely dependent on their trading activity; it may be to speculate on market information or portfolios diversification for risk sharing, or else the need for liquidity. These different motives to trade are a result of processing different available information. In consequence, trading volume may originate from any of the investors who may have different information sets. As various studies reported, the information flow into the market is linked to the trading volume and volatility (Gallant, Rossi and Tauchen, 1992). Thus, since the stock price changes when new information arrives, there exists a relation between prices, volatility and trading volumes (Lamoureux and Lastrapes, 1990 and He and Wang, 1995).

\section{Literature Review}

Trading volume has had mixed empirical results as a proxy for market liquidity. Fleming (2001) finds that trading volume is negatively correlated with the bid-ask spread and positively correlated with trade size, which suggests that a higher trading volume is associated with greater liquidity. He also finds, however, that trading volume is negatively correlated with quote size and positively correlated with the price-impact coefficient and the on-therun/off-the-run yield spread, which implies that a higher trading volume is associated with lower liquidity

Jun, Marathe and Shawky (2003) look into the relationship between returns and liquidity measures such as turnover ratio, trading volume and turnover-volatility ration for 27 emerging markets from 1992 until 1999. They show that stock returns in emerging markets are positively correlated with liquidity measures. In general, these studies demonstrate the existence of a relationship between liquidity and returns using different proxies in order to emphasise the role of liquidity in stock markets. This is an important determinant for companies, investors, regulators and the market itself.

Trade size is another measure of market depth. Although it does not reveal the depth of liquidity faced by market participants ex ante, as an ex post measure of realized depth it may be a more appropriate indicator if participants 
do not reveal their true trading intentions in their posted quotes. Trade size reflects the amount that was actually traded at the bid or ask, and includes any negotiations over size that may have taken place once the initial quote was hit or lifted. A comparison of the excess trade size and excess quote size for a particular security may indicate the relative importance of this practice.

Closely related to trading volume, trade frequency, or the number of trades observed per unit of time, is another indirect measure for liquidity. High trading frequency may reflect a more liquid market, but it may also be associated with increased price volatility, which is in turn associated with reduced liquidity. Since it does not include any effects from changes in trade size, however, it might be thought of that trade frequency as a "purer" measure of market activity than trading volume. Huang, Cai, and Wang (2001) find that trade frequency is more highly correlated with Treasury volatility than is trading volume. Fleming (2001) notes that trading volume has little incremental explanatory power over trade frequency in explaining price changes.

Datar, Narayan, and Radcliffe (1998) use turnover ratio as a liquidity measure and find a negative correlation between liquidity and returns for NYSE stocks. Similarly, Dey (2005) support a negative relation between returns and turnover but this relationship is valid for developed markets only as the emerging markets show a positive relationship.

\section{Data and Methodology}

The research study employed a Quantitative research design to analyses the effect of Bid Ask spread on excess returns in Nairobi Security Exchange (NSE) during the period 2006 to 2015. A census study was conducted for all the listed companies. Secondary data was used to construct the estimates for the function parameters. The data was extracted from the NSE records for ten years from 2006 to 2015. Data from the companies in NSE were collected on daily stock return (dependent variable) and independent variables which include data from the securities that looks at the bid ask spread. The NSE has 64 companies as at December 2016 and out of this 38 companies were used which had consistently listed during this period.

A time-series asset-pricing tests based on individual stock's realized returns was ran. An adjusted Fama and French (1993) three factor model methodology was used to run the time-series asset-pricing tests with Trading Volume as liquidity measures as indicated in equation.

$R_{i, t}=\alpha_{i}+$ Fama - French three factor model + $a_{1, i}$ Trading Volume $+\varepsilon_{i, t}$ 


\section{Fama-French three factor model}

To establish the effect of Fama and French three factors (1993) the model below was used.

$R_{i, t}=\alpha_{i}+b_{1, i} M K T_{t}+b_{2, i} S M B_{t}+b_{3, i} H M L_{t}+\varepsilon_{i, t}$

Where: $M K T$ is the Market Premium

$S M B_{t}$ is Small minus Big. Which is the return at day t on the FamaFrench size factors

$H M L$ is High minus Low. Which is the return at day t on the FamaFrench size factors

$R_{i, t}$ is excess realized return for portfolio i at over time t.

Six portfolios were formed based on Fama-French three factor model (1993) as shown in table 1. The portfolios were formed from the listed companies which were listed from the duration of January 2006 to December 2015. A firm qualified to be in the portfolio on the basis of having continuous listing over the years under study. This is because the effects of market liquidity is a long term study.

Table 1: Portfolio formation

\begin{tabular}{|c|c|c|}
\hline & Size of company (ma & et value of equity) \\
\hline \multirow{3}{*}{$\begin{array}{c}\text { Ratio of book } \\
\text { value of equity to } \\
\text { it market value } \\
\text { (Book-to-market } \\
\text { value of equity) }\end{array}$} & $\begin{array}{c}\text { Small companies } \\
\text { Small size/Low value companies } \\
\text { (S/L) (portfolio one) }\end{array}$ & $\begin{array}{c}\text { Big companies } \\
\text { Big/ low value }(\mathrm{B} / \mathrm{L})(\text { portfolio } \\
\text { Four })\end{array}$ \\
\hline & $\begin{array}{c}\text { Small size/ Medium value } \\
\text { (companies)(S/M) (portfolio two) }\end{array}$ & $\begin{array}{c}\text { Big size/ medium value } \\
(\mathrm{B} / \mathrm{M})(\text { portfolio } \\
\text { Five })\end{array}$ \\
\hline & $\begin{array}{l}\text { Small size/High value companies } \\
\text { (S/H) (portfolio three) }\end{array}$ & $\begin{array}{l}\text { Big size /high value }(\mathrm{B} / \mathrm{H}) \\
\text { (portfolio Six) }\end{array}$ \\
\hline
\end{tabular}

\section{Trading Volume}

To establish the effects of Trading Volume on asset pricing in Nairobi Security Exchange (NSE) in Kenya. Porter (2003) presents the following measures of Trading Volume:

$$
V 0 l_{t}=\sum_{t=1}^{n} P_{i t} Q_{i t}
$$

Where $V 0 l_{t}$ is the total trading volume.

$P_{i t}$ is the price of security $i$ and

$Q_{i t}$ is the quantity of security $\mathrm{i}$

\section{Result and Finding}

The Summary statistics that encapsulate the measures of central tendency such as the mean, the measures of dispersion such as standard 
deviation, minimum and maximum observations, measures of distribution such as Skewedness and Kurtosis and Jarque-bera test were used are illustrated in Table 2.

Table 2: Descriptive Statistics

\begin{tabular}{crrrrr}
\hline & $\begin{array}{c}\text { Average } \\
\text { Return }\end{array}$ & $\begin{array}{c}\text { Market } \\
\text { Premium }\end{array}$ & \multicolumn{1}{c}{ SMB } & \multicolumn{1}{c}{ HML } & Log T. Volume \\
Mean & -7.330686 & -6.803071 & -0.167297 & -0.786908 & 15.02548 \\
Median & -6.854795 & -6.905946 & -0.556892 & -0.990065 & 15.09791 \\
Maximum & 14.48663 & 8.164636 & 12.98585 & 16.79718 & 16.41880 \\
Minimum & -24.74673 & -20.43586 & -12.73600 & -19.91744 & 13.51109 \\
Std. Dev. & 6.985605 & 5.347939 & 4.950712 & 5.573938 & 0.617705 \\
Skewness & -0.001304 & 0.092165 & 0.246903 & 0.093278 & -0.304915 \\
Kurtosis & 3.138488 & 3.225728 & 2.811885 & 4.267625 & 2.840323 \\
Jarque-Bera & 0.095928 & 0.424651 & 1.396158 & 8.208386 & 1.986944 \\
Probability & 0.953168 & 0.808701 & 0.497540 & 0.016503 & 0.370289 \\
Sum & -879.6823 & -816.3685 & -20.07560 & -94.42897 & 1803.058 \\
Sum Sq. Dev. & 5807.043 & 3403.454 & 2916.636 & 3697.185 & 45.40552 \\
& & & & & \\
Observations & 120 & 120 & 120 & 120 & 120 \\
\hline
\end{tabular}

The results in Table 2 shows the descriptive statistics included the mean of excess return, market premium, High Minus Low (HML), Small Minus Big (SMB), and Trading Volume variables. The average mean of excess return was -7.33 with a negative skewness. The Market premium, SMB, HML all have a negative mean with positive skewness, while the Trading Volume has a positive mean of $15.0254 \%$ with a positive skewness of -0.304915 . An analysis of the standard deviation reveals that all the variables have a positive standard deviation.

The Jarque-Bera test was used to determine whether study variables were normally distributed. The result of normally test were summarized in Table 2. The null hypothesis that sample data is not significant different than a normal population was determined using Jarque-Bera test that ranged from 0.095928 to 8.208386 meaning that some of the variables are not normally distributed.

The skewness and kurtosis test was to find out if the data is normally distributed. The test statistics is a chi-square distribution for skewness and kurtosis. The test is carried out against the null hypothesis of normal distribution. Average return and trading volume are negatively skewed while all the other variable are positively skewed. These values of skewness shows that the variables are not all normally distributed since their value of skewness disperse from zero. The Kurtosi values of SMB and trading volume are below 3 and the rest had kurtosis of more than 3 which was away from normal distribution. 


\section{Correlation Coefficient}

Table 3

\begin{tabular}{crrrrr}
\hline & avereturn & marketret & hml & smb & LogT Volume \\
avereturn & 1.000000 & & & & \\
marketret & 0.696601 & 1.000000 & & & \\
hml & -0.045768 & 0.185554 & 1.000000 & & \\
smb & -0.045805 & -0.128170 & -0.275138 & 1.000000 & \\
Log t volume & 0.286549 & 0.058875 & -0.118733 & -0.032928 & 1.000000 \\
\hline
\end{tabular}

Correlation test was carried out as in table 3 and none of the variable were greatly correlated with the other as shown in table 3 above with correlated with the other as shown in table 3 above with correlation coefficient ranging from -0.275136 to 0.696601 .

\section{Unit root test}

Table 4

Group unit root test: Summary

Series: Avereturn, marketret, smb, hml, avelt volume.

Date: 06/20/18 Time: 19:38

Sample: 2006M01 2015M12

Exogenous variables: Individual effects, individual linear trends

Automatic selection of maximum lags

Automatic lag length selection based on SIC: 0 to 1

Newey-West automatic bandwidth selection and Bartlett kernel

$\begin{array}{ccccc}\text { Method } & \text { Statistic } & \text { Prob.** } & \begin{array}{c}\text { Cross- } \\ \text { sections }\end{array} & \text { Obs } \\ \text { Null: Unit root } & \text { (assumes common unit root process) } & \\ \text { Levin, Lin \& Chu t* } & -10.2001 & 0.0000 & 5 & 594 \\ \text { Breitung t-stat } & -7.24678 & 0.0000 & 5 & 589\end{array}$

Null: Unit root (assumes individual unit root process)

$\begin{array}{crrrr}\text { Im, Pesaran and Shin W-stat } & -15.4035 & 0.0000 & 5 & 594 \\ \text { ADF - Fisher Chi-square } & 188.811 & 0.0000 & 5 & 594 \\ \text { PP - Fisher Chi-square } & 225.520 & 0.0000 & 5 & 595\end{array}$

** Probabilities for Fisher tests are computed using an asymptotic Chi -square distribution. All other tests assume asymptotic normality.

To test for unit root this study chose is Im, Pesaran and Shin (IPS), the Fisher-type Augmented Dickey and Fuller (ADF) and the Fisher-type Phillips and Perron (PP) tests with and without time trend. The null hypothesis was that panel data was non-stationarity.

Im, Pesaran and Shin (IPS) proposes a test for the presence of unit roots in panels that combines information from the time series dimension with that from the cross section dimension, such that fewer time observations are required for the test to have power. IPS test has been found to have superior 
test power by researchers in economics to analyze long-run relationships in panel data. Both the result of ADF and Phillips Perron (PP) are presented for comparison purposes. This is based on the observation by Maddala and $\mathrm{Wu}$ (1999) that unlike the ADF test which is parametric, the PP test is nonparametric and hence robust in presence of serial correlation in the error terms without adding lagged difference terms. In addition, the tests played a confirmatory and complementary role to the findings of LLC test.

The results from the unit root test for all the variables in in table 4 above shows that the variables in the group are stationary with P-Values of 0.0000 . Hence rejecting the null hypothesis that the variables in the group have a common unit root

\section{Heteroskedasticity Test}

The study further embarked on post-estimation test to test for the presence of heteroscedasticity and serial correlation as shown in table 5. In particular, autoregressive conditional Heteroscedasticity (ARCH) test was carried out to test for the stability of the variance on the residuals from the model. If the test statistics; F-statistic and Observation R-square are significant the model is said to have heteroscedasticity problem. If the two test statistics are insignificant the model is said to be stable and well identified.

Table 5

Heteroskedasticity Test: ARCH

\begin{tabular}{|c|c|c|c|c|}
\hline F-statistic & 0.088761 & \multicolumn{2}{|c|}{ Prob. F(2,115) } & 0.9151 \\
\hline Obs*R-squared & 0.181873 & \multicolumn{2}{|c|}{ Prob. Chi-Square(2) } & 0.9131 \\
\hline \multicolumn{5}{|c|}{$\begin{array}{l}\text { Test Equation: } \\
\text { Dependent Variable: RESID^2 } \\
\text { Method: Least Squares } \\
\text { Date: 06/20/18 Time: } 20: 03 \\
\text { Sample (adjusted): } 2006 \mathrm{M} 03 \text { 2015M12 } \\
\text { Included observations: } 118 \text { after adjustments }\end{array}$} \\
\hline Variable & Coefficient & Std. Error & t-Statistic & Prob. \\
\hline $\mathrm{C}$ & 21.52821 & 4.707314 & 4.573353 & 0.0000 \\
\hline $\operatorname{RESID}^{\wedge} 2(-1)$ & -0.017856 & 0.093228 & -0.191532 & 0.8484 \\
\hline $\operatorname{RESID}^{\wedge} 2(-2)$ & -0.034920 & 0.091863 & -0.380135 & 0.7045 \\
\hline R-squared & 0.001541 & \multicolumn{2}{|c|}{ Mean dependent var } & 20.42038 \\
\hline Adjusted R-squared & -0.015823 & \multicolumn{2}{|c|}{ S.D. dependent var } & 41.06322 \\
\hline S.E. of regression & 41.38682 & \multicolumn{2}{|c|}{ Akaike info criterion } & 10.30890 \\
\hline Sum squared resid & 196979.9 & \multicolumn{2}{|c|}{ Schwarz criterion } & 10.37934 \\
\hline Log likelihood & -605.2249 & \multirow{2}{*}{\multicolumn{2}{|c|}{$\begin{array}{c}\text { Hannan-Quinn criter. } \\
\text { Durbin-Watson stat }\end{array}$}} & 10.33750 \\
\hline F-statistic & 0.088761 & & & 1.988273 \\
\hline $\operatorname{Prob}($ F-statistic $)$ & 0.915127 & & & \\
\hline
\end{tabular}


The F-statistic and the Chi-square tests rejects the null hypothesis of heteroscedasticity, since the P-values of the two tests are statistically insignificant. The. F-statistic 0.088761, R-squared 0.001541 and the Adjusted R-squared -0.015823 are very low which means the variables used have no explanatory power on the dependent variable as shown in table 5 above.

\section{Autocorrelation Test}

The Breusch-Godfrey Serial Correlation LM Test of autocorrelation was also performed to test for the existence of the serial correlation among the error terms. Two test statistics were used these were; F-statistic, Observations*R-squared. If the statistics are significant, that indicates the presence of autocorrelation. If the test statistics are insignificant that indicate the absence of autocorrelation in the model.

\section{Table 6}

Breusch-Godfrey Serial Correlation LM Test:

$\begin{array}{cc}\text { F-statistic } & 0.812467 \\ \text { Obs*R-squared } & 1.701131 \\ & \\ \text { Test Equation: } & \\ \text { Dependent Variable: RESID } \\ \text { Method: Least Squares } \\ \text { Date: 06/20/18 Time: 20:02 } \\ \text { Sample: 2006M01 2015M12 } \\ \text { Included observations: } 120\end{array}$

Presample missing value lagged residuals set to zero.

\begin{tabular}{crrrr} 
Variable & Coefficient & \multicolumn{1}{l}{ Std. Error } & t-Statistic & Prob. \\
& & & & \\
MARKETRET & -0.011724 & 0.083505 & -0.140400 & 0.8886 \\
SMB & 0.004309 & 0.091563 & 0.047064 & 0.9625 \\
HML & 0.017951 & 0.084842 & 0.211579 & 0.8328 \\
AVELTURNOVER & -0.078172 & 0.708196 & -0.110382 & 0.9123 \\
C & 1.109334 & 10.68782 & 0.103794 & 0.9175 \\
RESID(-1) & 0.120880 & 0.095608 & 1.264323 & 0.2087 \\
RESID(-2) & 0.007843 & 0.097880 & 0.080129 & 0.9363 \\
& & & \\
R-squared & 0.014176 & Mean dependent var & $-4.80 \mathrm{E}-15$ \\
Adjusted R-squared & -0.038169 & S.D. dependent var & 4.594226 \\
S.E. of regression & 4.681083 & Akaike info criterion & 5.981499 \\
Sum squared resid & 2476.117 & Schwarz criterion & 6.144102 \\
Log likelihood & -351.8899 & Hannan-Quinn criter. & 6.047533 \\
F-statistic & 0.270822 & Durbin-Watson stat & 1.963457 \\
Prob(F-statistic) & 0.949532 & &
\end{tabular}


The F-statistic and the Chi-square tests rejects the null hypothesis of heteroscedasticity, since the P-values of the two tests are statistically insignificant. The. F-statistic 0.812467, R-squared 0.014176 and the Adjusted R-squared -0.038169 are very low which means the variables used have no explanatory power on the dependent variable as shown in table 6 above.

\section{Regression Analysis}

The value of adjusted R-squared was found to be 0.567470 shows that the independent variables in this portfolio are able to explain about of the variation in returns. The value of F-statistic of 37.71930 was also found to be statistically significant. The value of the Durbin Watson of Durbin-Watson statistic 1.72744 is also close to the critical value of 2 which indicate the absence of autocorrelation in the error terms.

\section{Table 7}

Dependent Variable: AVERETURN

Method: Least Squares

Date: 06/20/18 Time: 20:01

Sample: 2006M01 2015M12

Included observations: 120

$\begin{array}{crrrr}\text { Variable } & \text { Coefficient } & \text { Std. Error } & \text { t-Statistic } & \text { Prob. } \\ \text { MARKETRET } & 0.930241 & 0.082045 & 11.33814 & 0.0000 \\ \text { SMB } & 0.017474 & 0.090487 & 0.193109 & 0.8472 \\ \text { HML } & -0.184845 & 0.081807 & -2.259535 & 0.0257 \\ \text { Log T. Volume } & 2.572973 & 0.702280 & 3.663743 & 0.0004 \\ \text { C } & -39.80489 & 10.60826 & -3.752253 & 0.0003 \\ & & & \\ \text { R-squared } & 0.567470 & \text { Mean dependent var } & -7.330686 \\ \text { Adjusted R-squared } & 0.552425 & \text { S.D. dependent var } & 6.985605 \\ \text { S.E. of regression } & 4.673443 & \text { Akaike info criterion } & 5.962443 \\ \text { Sum squared resid } & 2511.723 & \text { Schwarz criterion } & 6.078588 \\ \text { Log likelihood } & -352.7466 & \text { Hannan-Quinn criter. } & 6.009610 \\ \text { F-statistic } & 37.71930 & \text { Durbin-Watson stat } & 1.727444 \\ \text { Prob(F-statistic) } & 0.000000 & & \end{array}$

\section{Market Premium}

There is a positive effect between the market premium and excess return. This is illustrated in table 7 where the coefficient of market premium was found to be 0.930241 meaning that an increase in the market premium by one percent causes the excess return on the portfolio to increase by 0.930241 percent. The coefficient is also statistically significant with a t-statistic value of 11.33814 The P-value was found to be 0.000 . The interpretation was that the variation between the excess return of firms in the in the NSE and the return on the market portfolio was very close to the actual expected value of 
one. These findings support those of who found that market beta had a significant effect on excess returns. These findings support those of Trimech et al. (2009), who's effort while investigating the market-factor effect in Tunisia, revealed that all estimated market coefficients were statistically significant at the 1 per cent level. Hence, they stated that the market risk is a key variable in capturing the cross-section of excess stock returns regardless of the assets forming the portfolios

Estrada (2011), employing regression analysis in the analysis in USA from the year 1977 to 2009 on excess found that the effect of market premium was positive and close to the pre-expected value of one. De Pena, Forner, and López-Espinosa, (2010) while evaluating the relevance of the Fama-French model in Spanish capital market and employing regression analysis found that market premium had a positive relationship with all portfolios in the market. These findings contradict those of $\mathrm{Xu}$, and Zhang (2014), in China who found that the market premium had positive and a statistically significant effect on the stocks return. Vakilifard, and Heirany, (2013), employed linear regression in Iran in an attempt to assess the role of Fama-French in assets pricing in Iran found that the market premium had a positive effect on the return of stocks. In essence the results in this paper support the traditional view that the market premium is key pricing of assets in Kenya context as well as globally.

\section{HML}

The value premium (HML) was -0.184845 showing that holding other variables in the model constant, an increase in the value premium by one percent causes the excess return on the portfolio to decrease by -0.184845 percent. The negative effect shows that there is an inverse relationship between the proxy for financial distress HML and excess returns of the firms in the portfolio one

The coefficient was statistically significant with a t-statistic value of 2.259535. The $\mathrm{p}$-value was found to be 0.0257 . The interpretation was that the relation between the excess return of firms in Kenya and HML premium was negative. Firms in kenya get higher returns as a result of value premium. These findings contradict those of Estrada (2011), who employing regression analysis in the analysis in USA from the year 1977 to 2009 on excess found that value premium had a positive effect on stock returns. De Pena, Forner, and López-Espinosa (2010), while evaluating the relevance of the FamaFrench model in Spanish capital market and employing regression analysis found that value premium had a positive relationship with some portfolios and a negative value with some other portfolios in the market. They support those of Xu and Zhang (2014), while investigating the relevance of the three factor model in pricing of assets in China found that the value premium had positive and negative effect on some of the portfolios and that the effect was a 
statistically significant. Vakilifard, and Heirany, (2013), employed linear regression in Iran in an attempt to assess the role of Fama-French in assets pricing in Iran found that the value premium had a negative effect on the return of stocks.

\section{SMB}

From the regression results in table 7 the coefficient of SMB was found to be -0.017474 . These values shows that holding other variables in the model constant, an increase in the size premium by one percent causes the excess return of the portfolio to decrease by $-0.017474 \%$. This shows that there is a positive relationship between the proxy for size and excess returns of the firms.

The coefficient is 0.193109 with $\mathrm{P}$-value of 0.8474 shows that it is not statistically significant. The interpretation was that the variation between the excess return of firms in Kenya and SMB was positive and it shows that in Kenya the returns of firms have a positive correlation with the premium for size.

These findings supports those of Trimech et al. (2009) in Tunisia, who note that the size factor represented by SMB, could have significant positive relationships with the stocks returns. Trimech et al. (2009) noted the estimated size effect was more pronounced for small portfolios than for big ones. Adami et al.(2014) in UK, also found similar results by revealing that the SMB coefficients were all positive indicating that in a given month the small capitalization stocks outperformed the large cap stocks. The size co-efficient values of all the deciles were found to be similar. De Pena, Forner, and LópezEspinosa (2010), while evaluating the relevance of the Fama-French model in spanish capital market and employing regression analysis found that size premium had a positive relationship with small size portfolios and a negative value with big size portfolios in the market. These results also support those of $\mathrm{Xu}$ and Zhang (2014), while investigating the relevance of the three factor model in pricing of assets in China found that the size premium had positive and negative effect on some of the portfolios and that the effect was statistically significant. Vakilifard and Heirany (2013), employed linear regression in Iran in an attempt to assess the role of Fama-French in assets pricing in Iran found that the size premium had a positive effect on the return of stocks. These results support those of Estrada (2011), employing regression analysis in the analysis in USA from the year 1977 to 2009 on excess found that size premium had a negative effect on stock returns.

\section{Trading Volume}

From the regression results in table 7 the coefficient of trading volume was found to be 2.572973 . This value shows that holding other variables in the model constant, an increase in spread by one unit causes the excess return 
of the portfolio to increase by 2.572973 units. The positive effect shows that there is a positive relationship between the trading volume (proxy for liquidity) and excess returns of the firms in Kenya.

The coefficient is not just positive but it is also statistically significant with a t-statistic value of 3.663743 and the P-value was found to be 0.0003 . The interpretation was that the variation between the excess return of firms in Kenya and trading volume is positive.

\section{Discussions}

Most of the research on establishing excess return in asset pricing do not use Market liquidity and its proxies such as trading volume as a risk factor. Majority of the studies such as Riro and Wambugu (2015), simply use market risk premium such as the one in CAPM, and Fama French factors to determine excess return.

In this study it is established that market liquidity as proxies by trading volume indeed has effects on the excess return. On average trading volume has a positive and statistically significant effect on excess return.

\section{Conclusion}

These paper analyse the effect of trading volume on excess return in Kenya by augmenting the Fama French in Kenya. Kenya is an emerging country that has growing stock market but is thin with very few stock. Multi linear regression analysis reveals that Market premium and HML and trading volume are important in explaining excess returns while SMB has a low explanatory power on excess return.

The finding of this study are significant to policy maker to formulate policies that increases trading volume as an important determinant to excess return. The policy formulated should be able to increase the listed companies in Kenya through listing of more companies and also cross listing across the markets. Regulations and incentives should be provided to enable smaller companies to list and encourage both local and foreign investors to invest in Kenya.

\section{References:}

1. Abbondante, P. (2010). Trading volume and stocks indices: A test of technical analysis. American Journal of Economics and Business Administration, 2 (3): 287-292

2. Adami, R., Gough, O., Mukherrjee, S., \& Sivaprasad, S. (2014). An empirical analysis of the performance of pension funds: evidence from UK. Studies in Economics and Finance, Vol. 31 Issue: 2, pp.141-155

3. Datar, V., Narayan N., \& Robert. R. (1998). Liquidity and stock returns: An alternative test. Journal of Financial Markets 1, 203-219. 
4. De Pena, F. J., Forner, C., \& López-Espinosa, G. (2010). Fundamentals and the Origin of Fama-French Factors: The Case of the Spanish Market. Finance a Uver, 60(5), 426.

5. Dey, M. (2005). Turnover and Return in Global Stock Markets. Emerging Markets Review, 6, 45-76.

6. Estrada, J. (2011). The Three-Factor Model: A Practitioner's Guide. Journal of Applied Corporate Finance, 23(2), 77-84.

7. Fama, E., \& French, K. (1993). Common risk factors in the returns on stocks and bonds. Journal of Financial Economics, 33, 3-56.

8. Fleming, M. (2001). Measuring Treasury market liquidity. Working paper, Federal Reserve Bank of New York, New York, NY.

9. Gallant, A.R., Rossi, P.E. and Tauchen G. (1992) Stock Prices and Volume. Review of Financial Studies, 5, 199242. https://doi.org/10.1093/rfs/5.2.199

10. He, H., and Wang, J. (1995) Differential Information and Dynamic Behavior of Stock Trading Volume. NBER Working Paper No. w5010. Available at SSRN: https://ssrn.com/abstract=225789

11. Huang, R. D., J. Cai, and X. Wang, 2002, "Information-Based Trading in the Treasury Note Interdealer Broker Market," Journal of Financial Intermediation, 11, 269-296.

12. Jun, S., Marathe, A., \& Shawky, H. A. (2003). Liquidity and stock returns in emerging equity markets. Emerging Markets Review 4 (2003) 1-24

13. Lamoureux, C., and Lastrapes, W. (1990). Heteroskedasticity in Stock Return Data: Volume versus GARCH Effects. Journal of Finance, 45: 221-229

14. Maddala, G. S., \& Wu, S. (1999). A comparative study of unit root tests with panel data and a new simple test. Oxford Bulletin of Economics and statistics, 61 (S1), 631-652.

15. Muriu, P. W., \& Achola, N. K. (2016). Testing the Three Factor Model of Fama and French: Evidence From An Emerging Market. European Scientific Journal Vol.12, No.16.

16. Riro,G.K., \& Wambugu, J. M. (2015). A Test of Asset-Pricing Models at the Nairobi Securities Exchange. Journal of Finance and Accounting, Vol.6, No.2.

17. Trimech, A., Kortas, H. Benammou, S. \& Benammou, S. (2009). Multiscale Fama-French model: application to the French market. The Journal of Risk Finance, Vol. 10 Issue: 2, pp.179-192.

18. Vakilifard, H. R., \& Heirany, F. (2013). A Comparative Evaluation of the Predictability of Fama-French Three-Factor Model and Chen Model in Explaining the Stock Returns of Tehran Stock Exchange. 
International Journal of Academic Research in Accounting, Finance and Management Sciences, 3(3), 118-124.

19. Xu, J., \& Zhang, S. (2014). The Fama-French Three Factors in Chinese Stock Market. China accounting and finance review vol. 16 no. 2 